\title{
Meningkatkan Kemampuan Menulis Puisi Bebas Melalui Media Biografi Tokoh Siswa Kelas VIII MTs NU Umbul Sari Kabupaten OKU Timur
}

Oleh

\author{
Herni Fitriani dan Sugiarti \\ STKIP Nurul Huda \\ Sukaraja OKU Timur \\ Email: hfitriani4@gmail.com
}

\begin{abstract}
The problem in this research is how the use of media biographies can improve the ability to write free verse in class VIII MTs NU Bannerman Sari East OKU District. This study aims to improve the ability to write free verse through the medium of biography. The subjects were students of class VIII MTs NU Bannerman Sari totaling 34 students. This research is a class act carried out in three cycles. Data collection techniques used are tests and observation. The use of biographical media can improve the ability to write free verse class VIII MTs NU Bannerman Sari East OKU District each cycle is the first cycle had an increase of $23.53 \%$, in the second cycle an increase of $26.47 \%$ from cycle 1 and cycle 3 had an increase of $29.41 \%$ from cycle 2 with an increasing average of $23.81 \%$.
\end{abstract}

Keywords: writing free verse biography media.

\section{PENDAHULUAN}

Pendidikan merupakan salah satu kunci bagi seseorang dalam mencapai kehidupan yang sukses. Ihsan (2010:4) mengatakan bahwa pendidikan bukan sekedar proses membekali siswa dengan ilmu pengetahuan tetapi juga membekali siswa dengan budi pekerti luhur.

Salah satu bentuk sastra paling terkenal dalam khasanah kesusastraan Indonesia adalah puisi. Berkaitan dengan sejarah perkembangan sastra puisi, Raminah (2007:3) menjelaskan sebagai berikut.

Puisi adalah seni kuno yang mulai dikenal sekitar tahun 3000 SM. Sisa-sisa tertua berasal dari Timur Dekat, pada tahun $2600 \mathrm{SM}$.
Bangsa Assyro-Babilonia, Sumeria, dan budaya. Sisasisa yang disimpan di cuneiform, sebuah tulisan kuno berbentuk baji pada tablet tanah liat, atau di atas kertas papirus stenciled dengan hieroglif, karakter yang digunakan dalam menulis gambar. Awal puisi ini termasuk memuji para dewa dan pahlawan, nyanyian atau lagu mengulangi catatan sama atau kata-kata, kebijaksanaan literature, daftar nasihat dan kebenaran dari orang tua atau otoritas lainnya, pesona sihir, dan ratapan untuk berkabung atau menginspirasi belas kasihan. 
Sastra puisi sejak perkembangannya hingga sekarang sangat dikenal oleh masyarakat. Puisi banyak disukai oleh masyarakat baik anak-anak, remaja, dewasa maupun usia tua. Daya tarik puisi terletak pada keindahan untaian bait-bait puisi menggambarkan suatu keadaan, perasaan, emosi, peristiwa dan lain sebagainya. Melalui kegiatan pembelajaran menulis puisi siswa diarahkan untuk mampu berkomunikasi menggunakan bahasa tulis. Siswa diharapkan mampu menuangkan gagasan atau idenya secara runtut dengan isi yang tepat, struktur benar sesuai konteksnya. Pembelajaran menulis mengarahkan siswa untuk mengungkapkan segala bentuk pikiran maupun ide berbentuk tulisan terstruktur.

Menulis puisi merupakan salah satu materi pembelajaran Bahasa Indonesia yang diberikan di kelas VIII semester genap. Hal tersebut sebagaimana tercantum pada Standar Kompetensi (16) Menulis: Mengungkapkan pikiran dan perasaan dalam puisi bebas, dan Kompetensi Dasar (16.1 dan 16.2). Materi pembelajaran menulis kreatif puisi sebagaimana dimaksud pada Standar Kompetensi dan Kompetensi Dasar tersebut, pada prakteknya menemukan berbagai kendala. Menurut Paryono
(2008:223), dalam pembelajaran sastra khususnya penulisan kreatif, salah satu kelemahan pembelajaran sastra di sekolah adalah materi pembelajaran sastra yang lebih menekankan kepada teori sastra dari pada pengakraban siswa dengan karyakarya sastra. Kondisi pembelajaran sastra demikian dan kurang mengakrabkan siswa pada karya sastra membuat siswa tidak mencintai sastra, berakibat siswa akan memiliki rasa malas untuk menulis. Selain itu, proses penyampaian materi sastra monoton dan tidak inovatif membuat siswa malas untuk mempelajari sastra.

Kendala atau kelemahan pembelajaran sastra aspek menulis kreatif puisi sebagaimana tersebut terjadi hampir di seluruh lembaga-lembaga pendidikan, tidak terkecuali di kelas VIII MTs NU Umbul Sari. Hal ini didasarkan pada nilai yang diperoleh siswa dari hasil tes menulis puisi masih rendah. Selain itu, partisipasi aktif siswa selama mengikuti pembelajaran juga menjadi acuan penilaian kemampuan menulis puisi. Selanjutnya nilai rata-rata keterampilan menulis siswa kelas VIII MTs NU Umbul Sari belum mencapai kriteria ketuntasan minimal, yaitu 70 .

Hal tersebut diperjelas dari dokumentasi nilai harian siswa pada materi pembelajaran menulis puisi. 
Dokumentasi nilai harian siswa kelas VIII MTs NU Umbul Sari menunjukkan rendah yaitu dari 34 siswa kelas VIII MTs NU Umbul Sari hanya terdapat 6 siswa yang memperoleh nilai $\geq 70$, sedangkan 28 siswa mendapatkan nilai $<70$. Data tersebut menunjukkan ketuntasan belajar aspek menulis puisi belum tercapai karena adanya permasalahan dalam kegiatan pembelajaran.

Data tersebut menunjukkan bahwa pembelajaran menulis puisi di kelas VIII MTs NU Umbul Sari belum mencapai ketuntasan. Sebab, berdasarkan buku petunjuk pelaksanaan pembelajaran di MTs NU Umbul Sari, pembelajaran bahasa Indonesia dikatakan tuntas apabila $\geq 85 \%$ dari jumlah siswa seluruhnya telah mencapai Kriteria Ketuntasan Minimal yang ditetapkan sebesar 70. Oleh karena itu, perlu dilakukan upaya atau tindakan perbaikan baik proses maupun hasil belajar menulis puisi siswa dalam hal ini dilakukan melalui penggunaan media biografi tokoh.

\section{TINJAUAN PUSTAKA}

Salah satu keterampilan berbahasa yang dibina pada pembelajaran Bahasa Indonesia adalah menulis. Tarigan (2008:22) mengatakan, menulis adalah menurunkan atau melukiskan lambang-lambang grafik untuk menggambarkan suatu bahasa yang dipahami oleh seseorang, sehingga orang lain dapat membaca lambang-lambang grafik itu. Dalam kegiatan menulis, penulis haruslah terampil memanfaatkan grafologi, struktur bahasa, dan kosa kata. Keterampilan menulis ini tidak akan datang secara otomatis, melainkan harus melalui latihan dan praktek dengan intensitas tinggi. Keterampilan menulis dalam kehidupan modern ini sangat dibutuhkan. Kiranya tidaklah terlalu berlebihan bila dikatakan bahwa keterampilan menulis merupakan suatu ciri dari orang terpelajar atau bangsa terpelajar.

Berdasarkan pengertian menulis dapat disimpulkan bahwa menulis merupakan kegiatan cukup kompleks. Perwujudannya diperlukan sejumlah persyaratan formal melibatkan berbagai faktor saling berpengaruh. Pemahaman yang baik terhadap aspek menulis ini, setidak-tidaknya akan membantu dalam mewujudkan program secara teoritis lebih seksama, sehingga penelaahan secara teoretis tentang aspek menulis banyak memberikan sumbangan bermanfaat.

Perumusan tujuan penulisan sangat penting dan harus ditentukan lebih dahulu karena hal ini akan merupakan titik tolak dalam seluruh kegiatan menulis tersebut. Rumusan tujuan penulisan adalah suatu gambaran penulis dalam kegiatan menulis 
selanjutnya. Tujuan penulisan akan mengarahkan penulis untuk memilih bahanbahan diperlukan, macam organisasi tulisan puisi akan diterapkan, atau mungkin juga sudut pandang akan dipilih. Tujuan merupakan penentu pokok untuk mengarahkan serta membatasi tulisan puisi. Kesadaran mengenai tujuan selama proses penulisan akan menjaga keutuhan tulisan. Hartig (dalam Tarigan 2008:25) mengatakan.

Tujuan kegiatan menulis ada tujuh, assigment purpose (tujuan penugasan), altruistic purpose (tujuan altruistik), persuasive purpose (tujuan persuatif), informational purpose (tujuan informational/tujuan

penerangan), self-expresive purpose (tujuan pernyataan diri), creative purpose (tujuan kreatif), problem-solving purpose (tujuan pemecahan masalah).

Tarigan (2008:21) menjelaskan langkah-langkah menulis yaitu penulis menurunkan gagasan-gagasannya, menerjemahkan gagasan tersebut ke dalam sandi lisan dan selanjutnya mengubah menjadi sandi tulis, mempergunakan sejumlah sarana untuk mekanis untuk merekam sandi tulis tersebut. Berdasarkan penjelasan tersebut dapat diambil simpulan bahwa tahap-tahap menulis mencakup tiga tahap, yaitu tahap pramenulis merupakan tahap perencanaan atau persiapan menulis, tahap penulisan membahas topik telah disusun, serta tahap revisi untuk menilai kembali apa yang sudah ditulis.

Puisi adalah bentuk kesusastraan paling tua. Puisi termasuk karya sastra, bersifat imajinatif. Bahasa sastra bersifat konotatif karena banyak digunakan makna kias. Dibandingkan bentuk karya sastra lain, puisi, lebih bersifat konotatif. Bahasa puisi lebih banyak mengandung kemungkinan makna. Hal ini disebabkan terjadinya pengonsentrasian atau pemadatan segenap kekuatan bahasa puisi.

Media pembelajaran telah dikenal sejak lama, sejak pendidikan formal atau pengajaran itu ada. Terdapat banyak pengertian atau definisi tentang media. Namun definisi-definisi tersebut yang muncul mengandung makna hampir sama. Sumiati (2008:119) mengatakan, secara etimologis, kata media adalah bentuk jamak dari medium, dalam bahasa latin berarti alat, sarana, maupun perantara.

Sumiati (2008:124) mengemukakan beberapa kemampuan media pengajaran dalam mengefektifkan proses belajar mengajar yaitu.

(1) Kemampuan fiksasi, yaitu media mempunyai kemampuan menangkap sesuatu objek atau peristiwa dan (2) Kemampuan manipulatif yaitu kemampuan memindahkan suatu objek disesuaikan dengan keperluan, kemampuan distributif yaitu 
memungkinkan mentransfer atau memindahkan suatu objek melalui ruang.

Arsyad (2011:27) mengatakan, media pembelajaran merupakan komponen instruksional meliputi pesan, orang, maupun peralatan. Dengan masuknya berbagai pengaruh ke dalam dunia pendidikan misalnya teori atau konsep baru serta teknologi, media pembelajaran terus mengalami perkembangan, tampil dalam berbagai jenis, dengan masing-masing ciri serta kemampuannya sendiri.

Arsyad (2011:19) mengklasifikasikan media atas empat kelompok yaitu (1) media hasil teknologi cetak, (2) media hasil teknologi audio-visual, (3) media hasil teknologi berbasis komputer, dan (4) media hasil gabungan teknologi cetak serta komputer. Glasgow (dalam Arsyad, 2011:19) membagi media ke dalam dua kelompok besar, yaitu media tradisional serta media teknologi mutakhir. Lebih lanjut Arsyad, (2011:21) menjelaskan sebagai berikut.

Media tradisional berupa media visual diam tidak diproyeksikan dan yang diproyeksikan, audio, penyajian multimedia, visual dinamis yang diproyeksikan, media cetak, permainan, dan media realia. Sedangkan pilihan media teknologi mutakhir berupa media berbasis telekomunikasi seperti teleconference dan media berbasis mikroprosesor seperti permainan komputer dan hypermedia.

Biografi merupakan kisah atau keterangan tentang kehidupan seseorang. Biografi biasanya lebih kompleks dari pada sekedar daftar tanggal lahir atau mati dan data-data pekerjaan seseorang, biografi juga bercerita tentang perasaan yang terlibat dalam mengalami kejadiankejadian tersebut. Darmawati (2013:92) menjelaskan bahwa kata biografi berasal dari bahasa Yunani yaitu kata bios yang artinya hidup, dan graphien yang berarti tulis. Biografi secara bahasa bisa diartikan sebagai sebuah tulisan tentang kehidupan seseorang, secara sederhana dapat dikatakan sebagai sebuah kisah riwayat hidup seseorang.

\section{METODOLOGI PENELITIAN}

Jenis penelitian yang digunakan adalah penelitian tindakan kelas (PTK) atau classroom action research yaitu suatu metode penelitian yang dilaksanakan di kelas tempat guru itu mengajar yang bertujuan untuk meningkatkan kemampuan para siswanya. Ide tentang penelitian tindakan pertama kali dikembangkan oleh Kurt dan Lewin pada tahun 1946. Menurut 
Stephen Kemmis (dikutip Rasyid, 2008:134) penelitian tindakan kelas atau action research adalah suatu bentuk penelaahan atau inkuiri melalui refleksi diri dilakukan oleh peserta kegiatan pendidikan tertentu dalam situasi sosial termasuk pendidikan untuk memperbaiki rasionalitas serta kebenaran dari praktik-praktik sosial atau pendidikan, pemahaman terhadap praktik-praktik pendidikan, dan situasi di tempat pendidikan dilaksanakan. Sukardi (2012:82) mengatakan tindakan kelas merupakan suatu jenis penelitian dilakukan oleh guru untuk memecahkan masalah pembelajaran di kelasnya.

\section{Tempat dan Waktu Penelitian}

Penelitian ini dilaksanakan di MTs NU Umbul Sari Kabupaten OKU Timur khususnya di kelas VIII. Penelitian ini merupakan penelitian tindakan kelas dengan pelaksanaannya di ruang kelas melalui proses pembelajaran. Oleh karena itu, waktu pelaksanaan penelitian ini disesuaikan dengan kalender pendidikan sekolah bersangkutan. Penelitian ini direncanakan akan dilaksanakan pada semester genap tahun pelajaran 2016/2017 yaitu pada bulan Februari sampai dengan bulan April 2016.

\section{Desain Penelitian}

Penelitian tindakan kelas merupakan bentuk penelitian dengan memberikan berbagai pelayanan tertentu untuk meningkatkan kualitas serta hasil belajar. Penelitian tindakan kelas dilaksanakan karena adanya suatu masalah dalam pembelajaran. Penelitian tindakan kelas merupakan proses pengkajian melalui sistem berdaur atau siklus dari berbagai kegiatan pembelajaran. Kemmis dan Mc Taggart (dikutip Asrori, 2008:7) menyatakan prosedur PTK dilaksanakan melalui 4 kegiatan utama atau tahapan yaitu plan (perencanaan). Action (tindakan), observation (pengamatan), reflection (refleksi).

\section{HASIL PENELITIAN DAN PEMBAHASAN}

Penelitian tindakan kelas ini bermula dari hasil observasi pendahuluan dalam pembelajaran menulis puisi di kelas VIII MTs NU Umbul Sari. Berdasarkan hasil observasi pendahuluan diketahui bahwa pembelajaran menulis puisi di kelas VIII MTs NU Umbul Sari dilaksanakan dengan menggunakan metode atau teknik pembelajaran konvensional seperti ceramah, diskusi serta penugasan, tanpa penggunaan media pembelajaran sehingga pembelajaran bersifat verbalistis. Keadaan pembelajaran 
demikian menjadikan aktivitas belajar serta kemampuan menulis puisi siswa menjadi rendah. Setelah diadakan penelitian terdiri dari tiga siklus dan ditempuh dalam 3 kali pertemuan dengan alokasi waktu 6 jam pelajaran diperoleh hasil sebagai berikut.

\subsection{Aktivitas Guru dalam Pembelajaran}

Aktivitas guru dalam pembelajaran dimaksudkan sebagai seluruh bentuk kegiatan dilakukan guru guna mengelola pembelajaran. Aktivitas guru selama pembelajaran pada penelitian ini diketahui menggunakan lembar observasi yang diisi oleh kolaborator. Adapun peningkatan aktivitas guru pada setiap siklusnya dapat dilihat pada tabel berikut.

TABEL 4.1

PENINGKATAN AKTIVITAS GURU

DALAM PEMBELAJARAN

SETIAP SIKLUS

\begin{tabular}{|c|c|c|c|}
\hline $\begin{array}{c}\text { Aktivitas } \\
\text { Guru }\end{array}$ & Siklus 1 & Siklus 2 & $\begin{array}{c}\text { Siklus } \\
\mathbf{3}\end{array}$ \\
\hline $\begin{array}{c}\text { Jumlah } \\
\text { Skor }\end{array}$ & 20 & 29 & 35 \\
\hline Prosentase & $55,56 \%$ & $80,55 \%$ & $97,22 \%$ \\
\hline Kategori & Baik & Baik & Baik \\
\hline
\end{tabular}

Tabel 4.1 menunjukkan bahwa aktivitas guru mengalami peningkatan pada setiap siklusnya. Rata-rata peningkatan prosentase aktivitas guru pada setiap siklus adalah 20,83\%. Untuk lebih jelasnya peningkatan aktivitas guru setiap siklusnya dapat dilihat pada grafik berikut.

DIAGRAM 4.1

\section{PENINGKATAN AKTIVITAS GURU PADA SETIAP SIKLUS}

\subsection{Aktivitas Belajar Siswa}

Aktivitas belajar siswa dalam pembelajaran menulis puisi melalui media biografi tokoh menunjukkan adanya peningkatan dari satu siklus perbaikan pembelajaran ke siklus berikutnya. Untuk lebih jelasnya peningkatan aktivitas belajar dalam setiap siklus dapat dilihat pada tabel berikut.

TABEL 4.2

PENINGKATAN AKTIVITAS BELAJAR SISWA SETIAP SIKLUS

\begin{tabular}{|c|c|c|c|}
\hline $\begin{array}{c}\text { Aktivitas } \\
\text { Siswa }\end{array}$ & Siklus & Siklus & Siklus \\
\hline $\begin{array}{c}\text { Jumlah } \\
\text { Skor }\end{array}$ & 246 & 308 & 363 \\
\hline Rata-rata & 7,24 & 9,06 & 10,68 \\
\hline Persentase & $60,29 \%$ & $75,49 \%$ & $88,97 \%$ \\
\hline
\end{tabular}

Tabel 4.2 menunjukkan bahwa terjadi peningkatan aktivitas belajar siswa kelas VIII MTs NU Umbul Sari pada setiap siklusnya. Rata-rata peningkatan aktivitas belajar siswa mencapai $14,34 \%$ pada setiap siklusnya. 


\section{SIMPULAN DAN SARAN}

\section{Simpulan}

Berdasarkan analisis dan pembahasan datadata hasil penelitian dapat disimpulkan sebagai berikut.

5 Pelaksanaan pembelajaran menulis puisi bebas melalui penggunaan media biografi tokoh di kelas VIII MTs NU Umbul Sari Kabupaten OKU Timur dilaksanakan melalui penelitian tindakan kelas yang terdiri atas 3 siklus. Masing-masing siklus terdiri atas empat tahapan yaitu perencanaan, pelaksanaan, observasi dan refleksi. Pada setiap pembelajaran siklus, siswa dilatih untuk dapat menulis teks puisi berdasarkan media biografi tokoh dengan penekanan pemahaman terhadap diksi, citraan atau pengimajian, penggunaan bahasa figuratif, penggunaan kata kongret, dan tipografi secara tepat.

6 Kemampuan menulis puisi bebas setelah penggunaan media biografi tokoh di kelas VIII MTs NU Umbul Sari Kabupaten OKU Timur mengalami peningkatan yang cukup signifikan setiap siklusnya yaitu pada siklus 1 terdapat 14 siswa atau $41,18 \%$ yang dapat mencapai ketuntasan, pada siklus 2 terdapat 23 siswa atau $67,65 \%$ mencapai ketuntasan dan pada siklus 3 dari 34 siswa terdapat 33 siswa atau $97,06 \%$ dapat mencapai ketuntasan.
7 Penggunaan media biografi tokoh dapat meningkatkan kemampuan menulis puisi siswa kelas VIII MTs NU Umbul Sari Kabupaten OKU Timur setiap siklusnya yaitu pada siklus 1 terjadi peningkatan sebesar 23,53\%, pada siklus 2 terjadi peningkatan sebesar $26,47 \%$ dari siklus 1 dan pada siklus 3 terjadi peningkatan sebesar 29,41\% dari siklus 2 dengan peningkatan rata-rata sebesar $23,81 \%$.

\section{Saran}

Berdasarkan hasil penelitian yang menunjukkan adanya peningkatan kemampuan menulis puisi bebas siswa kelas VIII MTs NU Umbul Sari Kabupaten OKU Timur melalui penggunaan media biografi tokoh, maka dapat disarankan sebagai berikut.

Bagi sekolah hendaknya dapat mengupayakan tersedianya berbagai media pembelajaran yang dapat digunakan guru dalam melaksanakan kegiatan pembelajaran seperti menyediakan berbagai literatur di perpustakaan agar dapat digunakan siswa untuk lebih memahami materi pembelajaran. Sekolah hendaknya memberikan pembinaan kemampuan berbahasa tulis bagi siswa melalui kegiatan-kegiatan edukatif seperti menyediakan majalah dinding sekolah 
maupun membuat majalah sekolah sebagai tempat menampung kreativitas menulis siswa.

Sedangkan bagi guru dalam melaksanakan pembelajaran bahasa Indonesia pada semua aspeknya, hendaknya dapat menerapkan berbagai metode pembelajaran yang diperkuat penggunaan media pembelajaran agar pesan pembelajaran dapat tersampaikan kepada siswa secara baik. Guru hendaknya memberikan berbagai latihan-latihan secara langsung bagi siswa dalam pembelajaran menulis seperti menulis puisi sehingga pemahaman siswa terhadap pembelajaran menulis tidak hanya bersifat teoretis.

Untuk siswa untuk mengasah kemampuan menulisnya, siswa hendaknya terus berlatih dengan menggunakan berbagai contoh tanpa harus menjadi plagiat. Siswa hendaknya dapat menggunakan berbagai sarana maupun media yang dapat mendukung perkembangan kemampuan menulisnya seperti memanfaatkan majalah dinding sekolah atau sekadar menulis pada web blog di media internet.

\section{DAFTAR PUSTAKA}

Arsyad, Azhar. 2011. Media Pembelajaran. Jakarta: Rajawali Press.

Asrori, Mohammad. 2008. Penelitian Tindakan Kelas. Jakarta: Raja Grafindo Persada.
Darmawati, Uti. 2013. Detik-detik Ujian Nasional. Jakarta: Tiga Serangkai.

Ihsan, Fuad. 2010. Landasan Kependidikan. Jakarta: Rineka Cipta.

Rasyid, Harun. 2008. Evaluasi Pendidikan. Bandung: CV. Wacana Prima.

Raminah. 2007. Apresiasi Puisi. Bandung: Angkasa.

Sukardi. 2012. Penelitian Tindakan Kelas. Jakarta: Rineka Cipta.

Sumiati dan Azra. 2008. Metode

Pembelajaran. Bandung: CV Wacana Prima.

Tarigan. 2008. Menulis Sebagai Suatu

Keterampilan Berbahasa. Bandung:

Angkasa. 